\title{
A HISTOCHEMICAL STUDY ON LEUCINOAMINOPEPTIDASE ACTIVITY IN THE SYNOVIAL MEMBRANE OF PATIENTS WITH RHEUMATOID ARTHRITIS
}

\author{
BY \\ UNTO VAINIO* \\ From the Rheumatism Foundation Hospital (Director: V. Laine, M.D.), Heinola, Finland
}

A joint affected with rheumatoid arthritis undergoes a number of pathological changes. The synovial membrane proliferates and begins to show round cell infiltration. Degenerative and proliferative changes are encountered in the arterioles and venules of the synovial membrane. Local necroses occur here and there in the tissue. The articular cartilage becomes thinner and spots of erosion appear in it, frequently extending up to the bone. A fluid is secreted into the joint, which differs in composition from normal synovial fluid.

Since such great morphological changes are seen in the joint, it may be expected that pathological changes also occur in the metabolism of the articular tissue. It has been shown that the presence of rheumatoid disease in the synovial membrane is accompanied by a very considerable increase in oxidative metabolism (Dingle and Thomas, 1956). Synthesis of synovial mucin takes place in the lining cell tissue of both normal and rheumatoid synovial membranes (Lever and Ford, 1958). Histochemical methods have been used to demonstrate several different enzymes in the hypertrophic lining cell tissue of patients with rheumatoid arthritis. Of the glycolytic enzymes, lactico-dehydrogenase-DPNHdiaphorase has been demonstrated; of the electron transport system, DPNH diaphorase; and of the Krebs tricarboxylic acid cycle, succinic dehydrogenase (Hamerman and Blum, 1959).

Cartilage erosion in rheumatoid arthritis usually first occurs at the point where the joint capsule is attached to the cartilage and pannus tissue grows over the articular surface ("chewing of cartilage"). It has been thought that enzymes secreted by the synovial pannus tissue are responsible for this cartilage degeneration (Bollet, 1963).

A chondromucoprotein complex occurs in the cartilage tissue. If the cartilage is subjected to

\footnotetext{
* Present address: Third Department of Medicine, University of Helsinki, Finland.
}

extracts of leucocytes or to extracts from the synovial membrane of a patient with rheumatoid arthritis, degeneration occurs, which has been attributed to some endopeptidase (Ziff, Gribetz, and Lospalluto, 1960).

The synovial fluid of patients with rheumatoid arthritis displays activity of several proteolytic enzymes, including pepsin, cathepsin, and trypsin (Vartio, 1960). Aminotripeptidase activity also occurs in proportion to the activity of the disease, abating as the disease becomes less acute (Hüttl and Marcović, 1963); these authors therefore suggest that it should be used to assess disease activity and the patient's recovery.

The collagen of a patient with rheumatoid arthritis deviates from normal in that two normally demonstrable peptides are missing in its hydrolysate (Steven, 1964).

Leucinoaminopeptidase (LAP) is an endopeptidase capable of hydrolysing peptides having a free $a$-amino group on a terminal leucine amino acid. LAP activity is normally encountered in intestinal and pancreatic secretions and in numerous tissues, the serum LAP activity being raised, for example, in association with carcinoma of the pancreas (BraunFalco, Salfeld, and Braun-Falco, 1959). Such activity has been demonstrated histochemically in the stroma of malignant tumours and the surrounding tissue (Burstone, 1956), being strongest at the point where the tumour shows invasive growth. No LAP whatever is demonstrable, for example, in the normal mucosa of the human stomach, but distinct activity is present in cases of carcinoma of the ventricle (Willighagen and Planteydt, 1959).

LAP may act as a protein-synthesizing agent, the LAP activity in the parathyroid gland being proportional to the activity of the gland (Pearse and Tremblay, 1958).

Subcutaneous nodules in cases of rheumatoid arthritis also display very marked LAP activity (Burstone, 1956, 1962). 


\section{Material and Methods}

Samples of pathological tissue were taken from forty patients fulfilling the American Rheumatism Association criteria for definite rheumatoid arthritis (Ropes, Bennett, Cobb, Jacox, and Jessar, 1959) who were admitted to the Rheumatism Foundation Hospital in 1965 . Five control specimens were taken from patients not suffering from rheumatoid arthritis: three of them had been subjected to arthrotomy for the repair of a meniscus rupture, and two samples were taken from amputated limbs.

All specimens were immediately frozen with dry ice in the operating theatre, and sectioned with a cryostatic microtome. The method described by Nachlas, Crawford, and Seligman (1957), having L-leucyl- $\beta$-naphthylamide as substrate, was used to localize LAP activity in the sections made at 12 to $24 \mu$. The specimens obtained from patients with rheumatoid arthritis were incubated $\frac{}{\omega}$ for 15 to 20 minutes, whereas the incubation period was 15 to 90 minutes for the control specimens, in order to elicit positive reactions.

\section{Results}

Slight LAP activity was seen in the control specimens, but not until after about 60 to 90 minutes' $s$ incubation. In all controls such activity was noted $\vec{\circ}$ in the fibroblasts and mast cells. Three controls $\vec{\overrightarrow{ }}$ also displayed distinct LAP activity in the lining cells of the synovial membrane (Fig. 1).

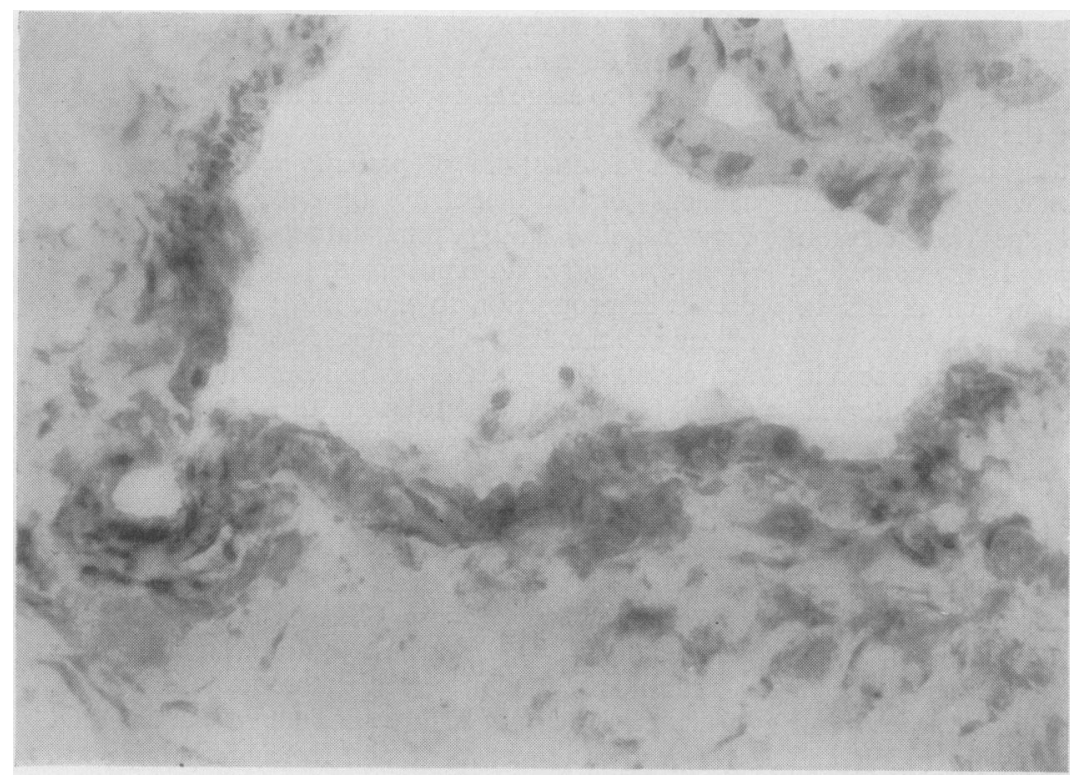

Fig. 1.-Normal synovial membrane. LAP activity is particularly seen as a narrow zone in the lining cells of the synovial membrane. $\times 200$.

Fig. 2.-Rheumatoid arthritis. Distinct LAP activity in lining cells of synovial membrane. $\times 200$.

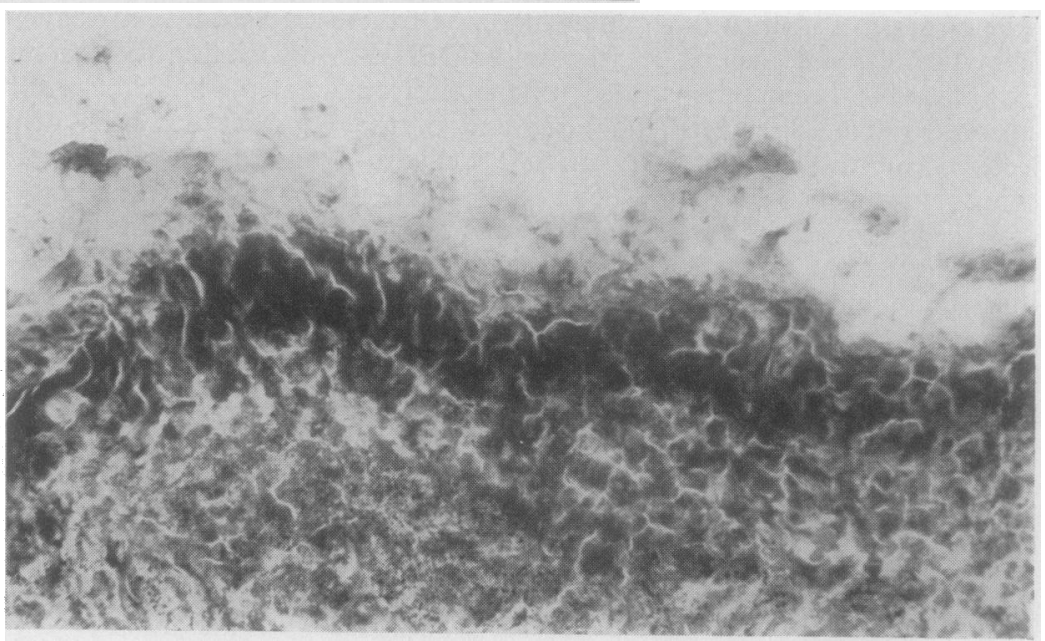


Distinct LAP activity was seen in all the rheumatoid specimens. The incubation period had to be limited to 15 to 20 minutes, as prolonged incubation resulted in enzymatic reaction of such strength that the histological examination of the section was impeded by the powerful colour reaction. LAP activity was localized in:

(1) The lining cells of the synovial membrane;

(2) The hyperplastic villi;
(3) Areas of fibrinoid necrosis sometimes found above the lining cell tissue;

(4) Around blood vessels and in their walls, also in the intima;

(5) Areas of fibrinoid necrosis in the tissue;

(6) Fibroblasts;

(7) Mast cells.

Examples are shown in Figs 2 to 4, and Fig. 5 (overleaf).

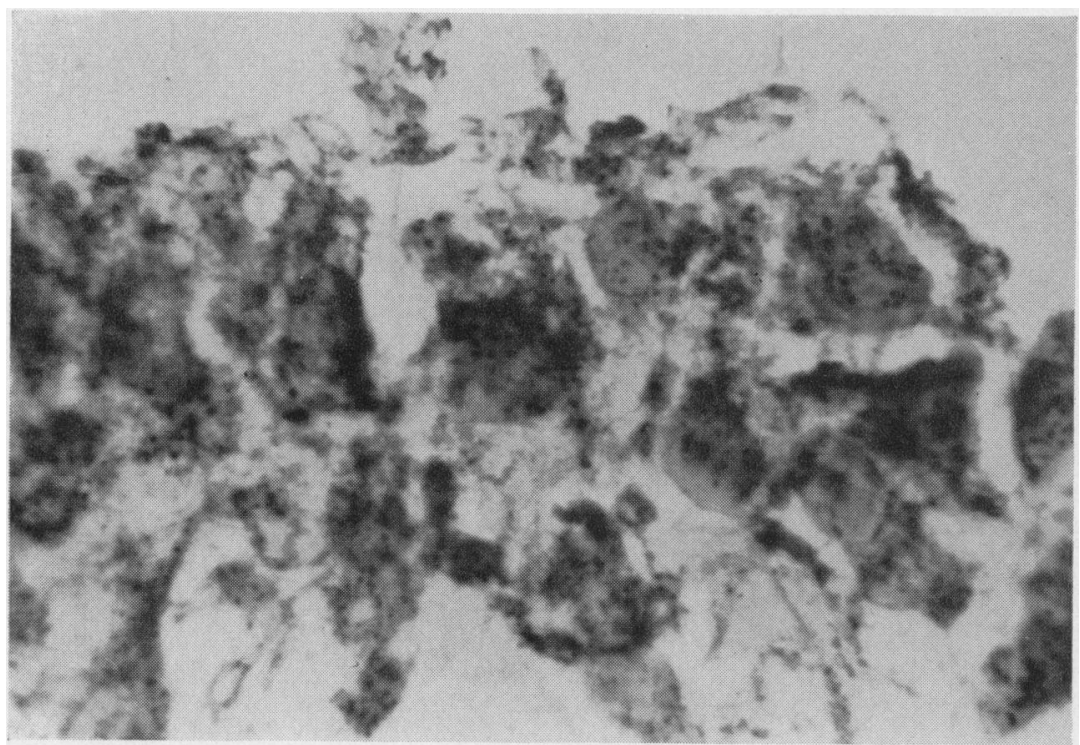

Fig. 3.- Same patient as in Fig. 2. Synovial lining cells, showing LAP activity localized in small granules, which occur in abundance in the cytoplasm of each cell. $\times 850$.

Fig. 4.-Rheumatoid arthritis. Strong LAP activity in recess between hypertrophic villi. $\times 200$.

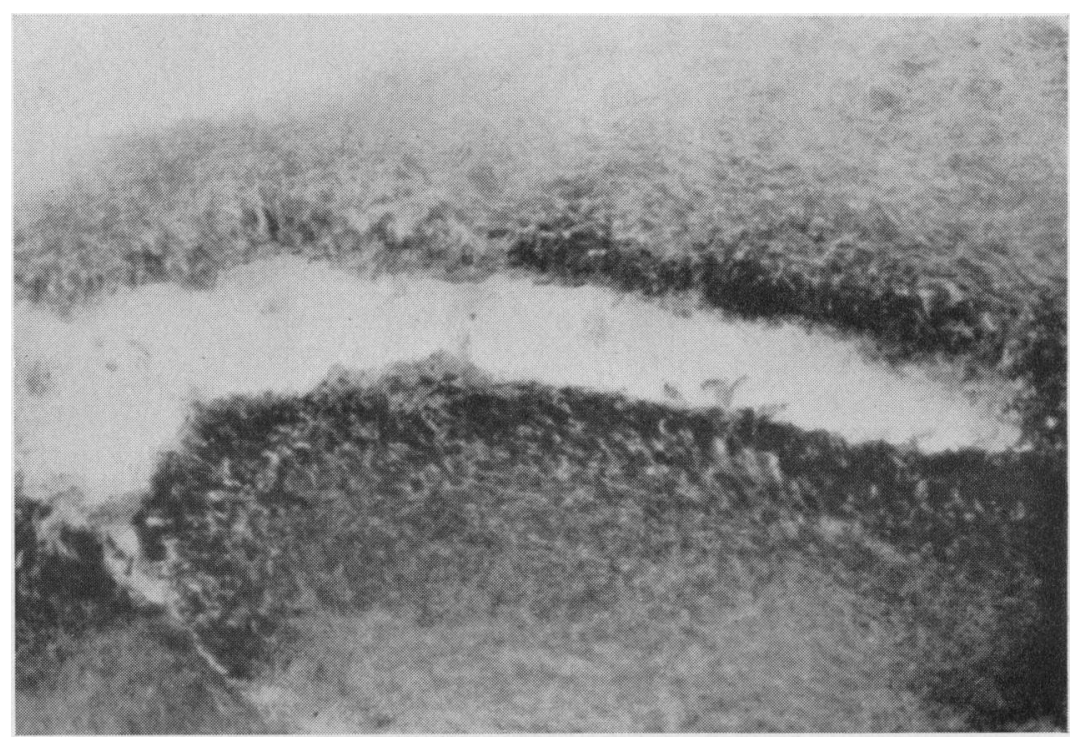




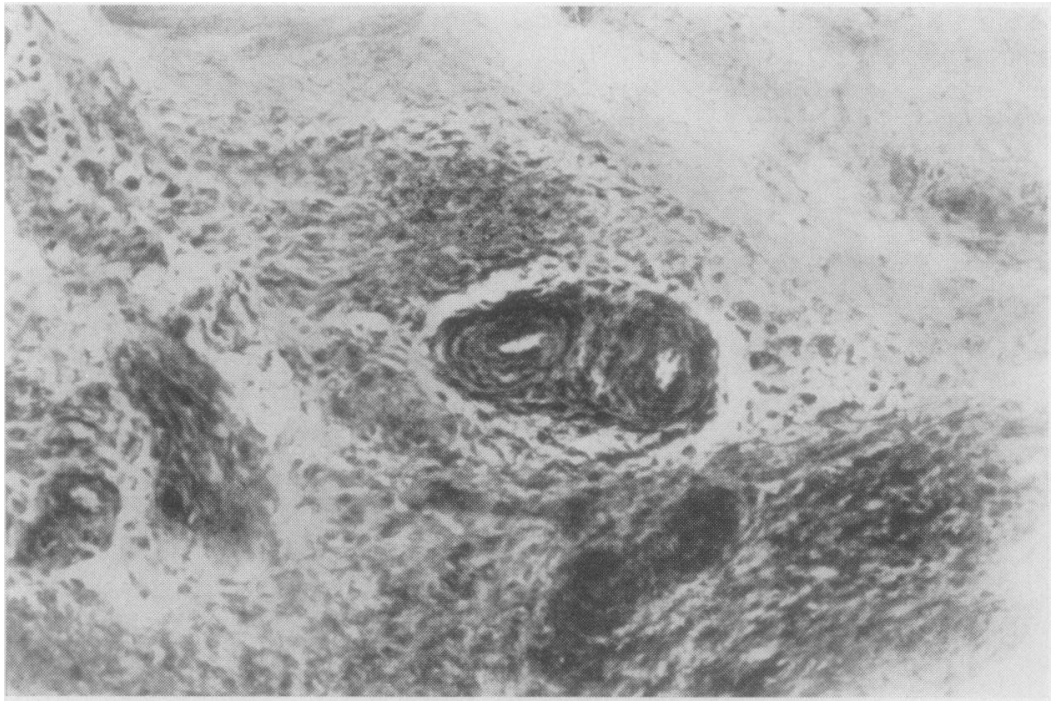

Fig. 5.-Rheumatoid arthritis. LAP activity in wall of a small arteriole, in its intima, and around the vessel. $\times 85$.

The occurrence of LAP was studied at the point where cartilage erosion could be assumed to be just beginning; a sample was taken from the end of the metatarsal bone, where the pannus tissue had grown over the articular cartilage and small erosions could be seen macroscopically. A section stained with haematoxylin and eosin shows the sharp demarcation between cartilage and connective tissue. LAP activity is seen in the connective tissue in the eroded pit. At high magnification an LAP zone is seen exactly at the line of demarcation (Fig. 6, and Fig. 7, opposite).

A specimen taken from the same patient, from a joint apparently unaffected, from the point where the joint capsule attaches to the cartilage, revealed that $\bar{z}$ strong LAP activity was already present in the connective tissue (Fig. 8, opposite).

LAP activity closely similar to that in the joint capsule was observed in five cases of tenosynovitis with rheumatoid arthritis and in three subcutaneous nodules (Fig. 9, opposite), the latter being consistent with the localization described by Burstone (1956, 1962).

\section{Discussion}

The role of LAP in the human organism is not yet exactly understood. It is known that LAP catalyses?

Fig. 6.-Rheumatoid arthritis. This specimen was taken from a point where the articular cartilage was covered by pannus tissue and showed distinct erosion. The same joint displayed manifest erosions on $x$ ray. Cartilage and fibrous tissue are sharply demarcated. LAP activity is seen in the pannus tissue and on the line between cartilage and pannus tissue. $\times 85$.

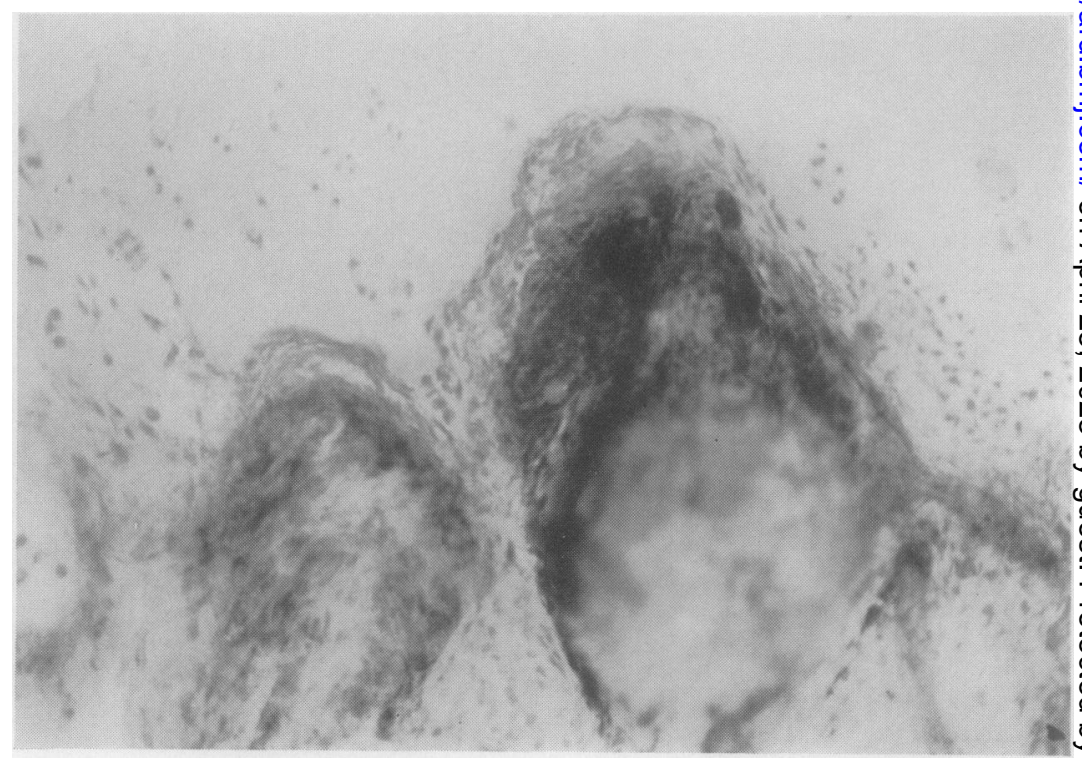




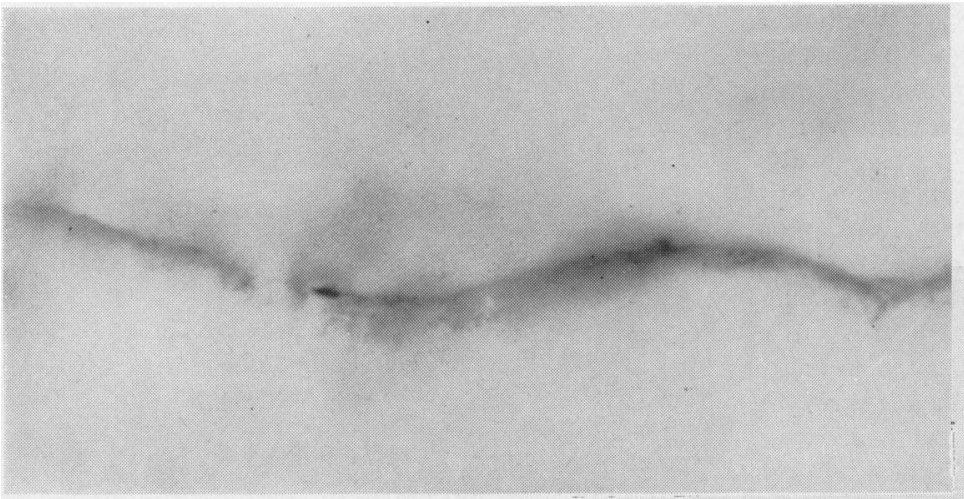

Fig. 7.-Same preparation as in Fig. 6. LAP tissue and cartilage. $\times 850$.

Fig. 8.- Same patient as in Figs 6 and 7 . Specimen taken from a macroscopically intact joint; here, too, LAP activity is seen on the boundary between cartilage and pannus tissue. $\times 85$.

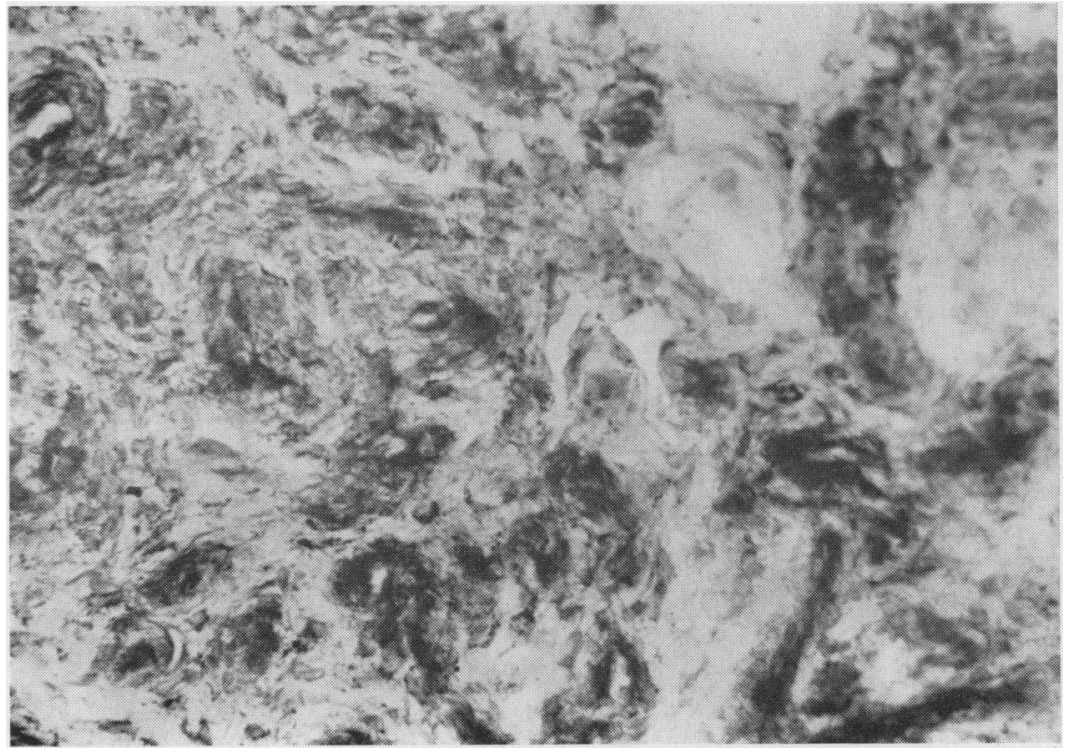

Fig. 9.-Rheumatoid nodule. Dis- $\frac{D}{9}$ tinct LAP activity in entire tissue sample. Marked localization around blood vessels and clearly observed $N$ activity in fibroblasts. LAP activity occurs where fibrinoid degeneration is encountered. $\times 200$. 
both lytic and synthetic reactions, and also that it occurs in healing skin wounds. It is present in malignant tumours, but it is not yet known whether it is associated with the invasive growth of the tumour as a promoting factor or whether it is a manifestation of the tissue's reaction against invasion. The same question arises when the significance of LAP in the pathogenesis of rheumatoid arthritis is considered. To think of it as a lytic enzyme which, upon being liberated from the synovial pannus tissue, attacks the cartilage in front of it, is consistent with the observed localization on the line of demarcation between cartilage and pannus tissue. On the other hand, the assumption that LAP acts as a catalyst to synthesis, is consistent with its localization in the lining cells of the synovial membrane. It should be remembered that the lining cell tissue of the synovial membrane is known to be the site of a number of synthetic functions: this tissue certainly synthesizes hyaluronates and acid mucopolysaccharides, and the appearance of LAP in the synovial membrane may also be connected with the phagocytizing function of the membrane.

\section{Summary}

The localization of leucinoaminopeptidase (LAP) in the synovial membrane, tenosynovial and pannus tissue, and adjoining articular cartilage of patients with rheumatoid arthritis has been studied by a histochemical method. LAP activity occurred in cases of rheumatoid arthritis more strongly than in corresponding, normal control specimens. The occurrence of LAP in areas of cartilage erosion adjacent to the pannus tissue may indicate that LAP is involved in the pathogenesis of cartilage erosion. The presence of LAP in rheumatoid arthritis is compared to its appearance in malignant neoplasms.

\section{REFERENCES}

Braun-Falco, O., Salfeld, K., and Braun-Falco, F. (1959). Klin. Wschr., 37, 231.

Bollet, J. A. (1963). J. chron. Dis., 16, 853.

Burstone, M. A. (1956). J. Nat. Canc. Inst., 16, 1149.

- (1962). "Enzyme Histochemistry and its Application in the Study of Neoplasms", p. 409. Academic Press, New York and London.

Dingle, J. T. M., and Thomas, D. P. Page (1956). Brit. J. exp. Path., 37, 318.
Hamerman, D., and Blum, M. (1959). Arthr. and Rheum., 2, 553.

Hüttl, S., and Marcović, O. (1963). Bratisl. lek. Listy, 음 $43,585$.

Lever, J. D., and Ford, E. H. R. (1958). Anat. Rec., 132, 525.

Nachlas, M. M., Crawford, D. T., and Seligman, A. M. (1957). J. Histochem. Cytochem., 5, 264.

Pearse, A. G. E., and Tremblay, G. (1958). Nature (Lond.), 181, 1532.

Ropes, M. W., Bennett, C. A., Cobb, S., Jacox, R., and Jessar, R. A. (1959). Ann. rheum. Dis., 18, 49.

Steven, F. S. (1964). Ibid., 23, 405.

Vartio, T. (1960). Ann. Med. exp. Fenn., 38, 94.

Willighagen, R. G. J., and Planteydt, H. T. (1959). Nature (Lond.), 183, 263.

Ziff, M., Gribetz, H. J., and Lospalluto, J. (1960). J. clin. Invest., 39, 405.

Une étude histochimique de l'activité de la leucinoaminopeptidase dans la membrane synoviale des malades atteints d'arthrite rhumatismale

\section{RÉSUMÉ}

On a étudié par une méthode histochimique la localisation de la leucinoaminopeptidase (LAP) dans la membrane synoviale, dans le tissu ténosynovial et paraarticulaire ainsi que dans le cartilage articulaire adjacent des malades atteints d'arthrite rhumatismale. L'activité de la LAP se manifestait plus fortement dans les prélèvements des cas d'arthrite rhumatismale que dans ceux des témoins. La présence de la LAP aux endroits de l'érosion cartilagineuse adjacente au tissu conjonctif para-articulaire peut indiquer que la LAP est impliquée dans la pathogénie de l'érosion cartilagineuse. On compare la présence de la LAP dans l'arthrite rhumatismale et son apparence dans les néoplasmes malins.

\section{Estudio histouqímico de la actividad de la leucinoaminopeptidasa en la membrana sinovial de enfermos con artritis reumatoide}

Sumario

Se estudió por un método histoquímico la localización de la leucinoaminopeptidasa (LAP) en la membrana sinovial, en el tejido tenosinovial y yuxta-articular, así como en el cartílago articular adyacente de enfermos con artritis reumatoide. La actividad de la LAP se manifestaba con mayor fuerza en los cortes de los casos de artritis reumatoide que en los de testigos. La presencia de la LAP en sitios de erosión cartilaginosa adyacente al tejido conectivo yuxta-articular puede indicar una implicación de la LAP en la patogénesis de la erosión cartilaginosa. La presencia de la LAP en la artritis reumatoide se compara con su apariencia en neoplasias malignas. 